\title{
INTRODUCTION
}

In November 1792 there was an explosion of gas at Benwell Colliery, Newcastle-upon-Tyne. Among the victims was James Jackson, a thirty-sixyear-old miner, who suffered significant injuries to his face, neck, part of his breast, hands and arms. Burns to his lips and nostrils indicated that he had suffered some internal injuries. When rescuers found him he was shivering, which suggested, in the words of Edward Kentish, the surgeon who treated him, that he had suffered a 'violent shock to the general system'. In the weeks following the accident, Jackson underwent a lengthy and uncomfortable course of treatment. His hands were washed with 'heated essence of turpentine', before being covered with plasters. He was given laudanum for the pain and a teacup full of 'oily emulsion, with an ounce of camphorated tincture of opium' every three hours. His injuries required round-the-clock attention, with bandages applied and reapplied and emollient rubbed on his burnt parts, but at length he began to recover. The skin started to return to his face and hands after a fortnight, and within six weeks Jackson was deemed 'capable of work'. Kentish recorded with pride that his treatment plan had 'combined everything I had to wish: it saved life, it eased pain, and it speedily restored my patient to health and usefulness'. And so Jackson was able to return to work, albeit with a body likely permanently scarred with physical reminders of the dangers of his occupation. ${ }^{1}$

Jackson was a survivor, but many victims of mining accidents were not so fortunate. Fatal accidents, such as the large-scale disasters that claimed 204 lives at Hartley Colliery in Northumberland in 1862 or, worst of all, the explosion that killed 439 men and boys at Universal Colliery, Senghenydd, in 1913 are well known. ${ }^{2}$ But as John Benson has pointed out, many British miners were killed in smaller accidents that claimed one or two lives. Still more suffered non-fatal injuries, or contracted chronic diseases that sapped their strength and shortened their lives. ${ }^{3}$ Dr James Mitchell, presenting evidence 
in 1842 to a commission set up to examine the employment of children in coal mines, documented a series of accidents at several unnamed Durham collieries. They included a worker who had lost his leg 'in consequence of coal falling upon it' and one who 'got two fingers taken off by the waggons jamming his hand', leaving him 'maimed'. Another worker, hurt by falling under a horse, 'was five months off work and remains weakly'. The accident had left him 'a little distorted, but not so as to impede him from working'. As the geologist Henry de la Beche told a House of Lords committee in 1849, although such accidents were 'very considerable', they did not 'excite the notice which is occasioned by explosions in the larger collieries'. 'A great many are occasionally disabled who are never heard of,' he noted, and were subsequently forced into dependency on poor relief 'in consequence of injuries that no one ever hears of.' ${ }^{5}$

This book examines the lives and experiences of these people, men like James Jackson, who, until recently, were 'never heard of' in histories of industrialisation - the scarred, the mutilated, the 'distorted' and the impaired. The process of industrial growth in Britain after 1700, which gathered pace from the late eighteenth century, orchestrated changes in professional, family and community, political and cultural life as well as in the economy and technology. Since the late 1960s, such processes have been examined via perspectives ranging from business history to gender history. Yet disability history is absent from this intellectual endeavour. ${ }^{6}$ As we show in the pages that follow, disability was central to the Industrial Revolution. Worries about disability and what to do about the seemingly countless numbers of workers injured in the service of industry prompted policy innovations that continue to affect the lives of Britons today, such as workplace health and safety regulations; age restrictions on when people can start work; and medical institutions catering for specific populations. Not only did disability become visible in its modern forms during the period, it also helped nineteenth-century Britons make sense of the momentous changes happening around them. The existence and experiences of chronically ill or maimed workers were regarded by many as proof of the evils of industrialism, providing a rallying call for the nascent labour movement and a rationale for worker-led campaigns and mutualism that fed their developing class consciousness. Disabled people, as we shall see, contributed to Britain's industrial development, while disability in turn shaped responses to industrialisation.

Given the largely forgotten significance of disability in the Industrial Revolution, what happens to our view of industrialisation when we place people with impairments at the heart of the story? As the examples above suggest, experiences of injured workers resist straightforward generalisation. 
For those who became reliant on public welfare after becoming 'disabled', there were others for whom bodily impairment did not necessarily mean an end to their working lives. How did industrial expansion contribute to the incidence of injury, disease and impairment? What happened to those 'disabled' through accidents or disease during Britain's Industrial Revolution? How did people with impairments negotiate changing welfare and medical regimes of assistance, and what was the place of disability in industrial politics? Did industrial change lead to increasing marginalisation of 'disabled' people and how receptive was the workplace to men, women and children with impairments? And what does a study of the Industrial Revolution that foregrounds the experience of disabled people contribute to our understanding of work and its politics in the past?

This book attempts to answer these questions by examining perceptions and experiences of disability within the context of the British coal industry and Britons' responses to people in mining areas who today might be labelled 'disabled'. Coal provides a compelling case study for exploring occupational impairment in industrialising Britain. Coal was at the forefront of the Industrial Revolution, powering, for instance, the expansion of the metallurgical and manufacturing sectors. ${ }^{7}$ One of the largest employers of labour, moreover, the industry was one of the most dangerous to work in and mineworkers were exposed to a variety of hazards ranging from noxious and flammable gases to dust, rock falls and equipment failure. Not only were miners at greater risk than any other workers to fatal accidents, they were also at significant risk of injury or disablement, with perhaps 100 non-fatal accidents for every fatal one. ${ }^{8}$ In Benson's estimation, during the second half of the nineteenth century, 'a miner was killed every six hours, seriously injured every two hours, and injured badly enough to need a week off work every two or three minutes' . In contrast to histories of disability that explore the 'otherness' of physical difference, such as studies of disabled people's work as 'freak' show performers, this book explores the history of disability within communities where some degree of bodily damage was the norm rather than the exception, where injuries, diseases and ailments were accepted as daily occurrences. ${ }^{10}$

We examine responses to and experiences of disability in a formative period of industrial expansion - the so-called 'classical' phase of the Industrial Revolution. These responses and experiences, as we will see, played out and were shaped in coalfield communities that celebrated social solidarity on the one hand and individual self-reliance on the other. Beginning in 1780, just before the expansion of the Great Northern Coalfield in north-east England, the book addresses the processes of industrialisation related to coalmining and their implications for conceptions and experiences of disability. It sheds light 
on the various community, political, medical and welfare responses to workers' disability in the century before the 1880 Employers' Liability Act - a landmark, if flawed, legislative intervention that enshrined in law employer responsibility for workplace accidents that could have been prevented. ${ }^{11}$ The book therefore charts a shift from ad hoc responses to disability to the first signs of a more formal recognition of the needs of disabled workers in a period that is significant for the gradual evolution of 'disability' as a category distinct from other forms of disease or ill health. ${ }^{12}$ It examines the role of economic changes in shaping understandings and experiences of disability during this crucial era of industrial development. Different communal, welfare and medical responses to disablement are analysed alongside evidence that indicates the agency of people with impairments. Indeed, rather than seeing 'disabled' mineworkers simply as the victims of exploitative economic expansion, a key contention of this book is that these people made important contributions to Britain's Industrial Revolution. 'Disabled' people were a conspicuous presence in industrialising Britain, in the workplace and as participants in the community life and industrial politics of Britain's coalfields. The remainder of this introductory chapter sets out the aims and objectives of the book in more detail and provides the historical and methodological context for the discussion that follows.

\section{Disability and industrialisation}

If disability has been largely absent from conventional histories of industrialisation, the Industrial Revolution has assumed great significance in disability studies. The idea that industrial economic development has had a profound impact on modern Western understandings and experiences of disability is a pervasive one in the field. Scholars influenced by historical materialism have been at the forefront of this kind of theorising. Writing in the 1980s, Vic Finkelstein provided one of the clearest and boldest statements of this position when he argued that 'disability' is essentially a creation of industrial capitalism. For him, the economic changes of the Industrial Revolution marked a decisive shift in the status of people with impairments during which they found it increasingly difficult to sell their labour on the same terms as others, leading to their increasing stigmatisation and isolation. This theory has been taken up and developed further by other scholars, most notably Michael Oliver and Colin Barnes, and Brendan Gleeson. ${ }^{13}$

Prior to industrialisation, it is argued, physically impaired people may have experienced poverty and stigma, but the organisation of society was such that it enabled them to participate in daily life to the best of their abilities. 
The predominantly agrarian nature of the pre-industrial economy, where production centred on the home and workers worked to task, meant that people had greater autonomy to decide their own work routines, rhythms and practices. Although impairment might prove challenging, then, the structure, requirements and expectations of pre-industrial life were flexible enough to allow permanently injured or chronically ill people to take up productive or other socially valued roles. With the coming of industrialisation, however, this 'somatic flexibility', as Gleeson terms it, was significantly undermined and impaired people were forced into less socially desirable positions. ${ }^{14}$

Building on Finkelstein and other materialist accounts, Oliver and Barnes point to four key 'disabling' elements of industrial societies: the growing speed of production associated with mechanised factory work; stricter discipline of workforces; more stringent time keeping; and the standardisation and regulation of production norms. Together, these are believed to have made workplaces hostile and unaccommodating environments for people with impairments. If they were not excluded from work altogether, impaired people were, at best, relegated to marginal productive roles that were poorly rewarded and of low status. As a result, people with impairments became 'disabled', stigmatised as unproductive and pushed to the margins of society. Increasingly regarded as a problem, disabled people in industrial societies were subjected to institutional 'solutions' that saw many placed in specially created facilities and segregated from the wider community. This belief in the institutionalising impulse of industrial societies was expressed most forcefully perhaps by Finkelstein. But others also maintain the premise, albeit in a slightly modified form. By the end of industrialisation, then, people with impairments were more likely to be seen as burdens than contributing members of society, better catered for in institutions than the community - at least in principle, if not in practice. $^{15}$

Although most clearly expressed and elaborated by historical materialists, this 'industrialisation thesis' about the conditions and forces responsible for the creation of modern Western 'disability' (as a distinct social category and experience) has passed uncritically into the work of many cultural disability studies scholars such as Rosemarie Garland Thomson. ${ }^{16}$ The broad appeal of materialist inspired accounts of disability is easy to understand. By calling attention to the structural basis of disabled people's experiences, they usefully show how disability is constituted in concrete ways. Barriers to paid employment, for instance, undoubtedly affect disabled people's position in society, as does the accessibility of the built environment. The analytic value of the industrialisation thesis in all its various guises is that it suggests the importance of changing material conditions and how these have affected the lives of 
people with impairments through history. The problem, however, is that its use as an explanatory framework is undermined by its lack of an adequate empirical foundation. Ideas about the Industrial Revolution's impact on disabled people's place in the world of work are central to the industrialisation thesis, but there are very few historical studies exploring the topic. Those that exist, moreover, tend to examine Western nations other than Britain, such as the United States or Belgium. ${ }^{17}$ However, while the employment prospects of impaired Britons during industrialisation have not yet received sustained investigation, their experiences are of immense significance to disability history and theory. As the world's first industrial nation, and an influential model for those that followed, Britain and its experience of industrialisation is crucial to our understanding of the origins and nature of disability in the West today.

The explanatory power of the industrialisation thesis in disability studies is also weakened, as Anne Borsay has noted, by its reliance on an over-simplified account of the Industrial Revolution that emphasises factory production at the expense of other sectors of the economy ${ }^{18}$ Industrialisation, however, was a multi-faceted and uneven process. Since the 1980s, economic historians have challenged the view that the Industrial Revolution marked a rapid and decisive shift to factory production and called into question the pace and impact of economic change. ${ }^{19}$ Factories may have sprung up in increasing numbers, but they were generally confined to relatively discreet manufacturing districts. They were not a ubiquitous feature of industrialising society. More important and common aspects of industrialisation included the growth of urban settlements, the increasing use of waged labour, increased mobility, the emergence of a market economy and intensification in the exploitation of natural resources. ${ }^{20}$ These broader dimensions of industrial change have rarely been studied from a disability perspective. This book therefore has a dual objective: to encourage historians of industrial society to incorporate experiences of disability into their analyses and to help disability scholars develop a more nuanced view of industrialisation by showing what can be gained when the focus of attention is shifted away from factories towards other important sites of industrial development - in our case, the mines and pit villages of industrialising Britain. Furthermore, people's relationship to work may be an important determinant of their social position and experiences as the industrialisation thesis maintains, but it is not the only one. In going beyond the workplace and looking at 'disabled' Britons' experiences in other areas of life during the Industrial Revolution, this book suggests how primarily economic meanings of disability could be mediated and challenged by, for example, disabled people's domestic, spiritual and social lives.

Indeed, those who witnessed the Industrial Revolution were far more con- 
cerned about the impact it had on the bodies of workers than what it meant for the employment prospects of 'disabled' people. Critics of mechanisation and reformers seeking to limit the employment of children in textile mills during the 1830 s routinely pointed to the damaging effects of factory work on the health, posture and well-being of employees. ${ }^{21}$ Some observers regarded conditions in collieries as even worse. A witness to the 1833 Factory Commission remarked that 'the hardest labour in the worst room in the worst-conducted factory is less hard, less cruel, and less demoralizing than the labour in the best of coalmines'. 22

Bodily non-normativity defined workers in industrialising Britain. For instance, William Dodd, the self-styled 'factory cripple' who campaigned against exploitative conditions of work in the woollen mills of northern England, wrote in 1841 that various categories of industrial worker could be defined by their 'shape', from 'in-kneed cripples' to those whose legs 'curved both outwards, so that a person may run a wheel-barrow between them'. Both were the result of excessive standing in one position, or the 'over-exertion' that Dodd complained was endemic in textile mills. ${ }^{23}$ Such claims were echoed in the critiques of industrial capitalism presented by Friedrich Engels and Karl Marx, who drew on government inquiries and factory inspector reports to show how new modes of production sacrificed the lives and limbs of workers. ${ }^{24}$ As the century progressed, eugenicists also called attention to the diseases and deformities of workers to illustrate fears that living conditions in industrial cities would 'produce an inferior race of urban degenerates' ${ }^{25}$

As Peter Kirby has cautioned, comments about the ubiquitous deformities or poor health of industrial workers were sometimes exaggerated and do not necessarily indicate the true scale of occupational disease and injury in industrialising Britain. ${ }^{26}$ However, by highlighting the presence of workers with impairments they do call into question the claim that industrialisation made it hard for impaired people to take up productive economic roles. If the Industrial Revolution did indeed make 'disabled' people, it should also be remembered that disabled people also helped make the Industrial Revolution. Rather than passive bystanders or victims of industrialisation, therefore, disabled people were actually active agents of economic change, though this is rarely acknowledged.

Put simply, then, a new approach to disability and industrial society is needed - one that takes into account the multi-faceted nature of industrial change and explores the dynamics of inclusion and exclusion within particular cohorts of workers or occupations, and in different settings. Sofie De Veirman's recent work, using census and other records to explore the changing work experiences of deaf people in eighteenth- and nineteenth-century Belgium, 
offers one fruitful way forward. ${ }^{27}$ By focusing on disability within a particular sector of the economy, rather than tracing the experiences of a single impairment group, we present another. Such an approach enables a more nuanced analysis of workers' experiences of impairment within the context of changing working practices, employer attitudes and industrial politics. It also takes into account the lives of disabled people beyond the workplace, to examine their familial, community and religious experiences. This moves us from a problematic general, all-encompassing theory of disabling industrialisation that privileges the world of work at the expense of other aspects of life, towards a history that makes room for the 'specific, local and personal'. ${ }^{28}$

Just as disability scholars and economic historians have failed to adequately recognise the productive contributions of disabled people in the past, so too have labour historians. Although occupational disease and injury have been major themes in labour history, labour historians hardly ever portray disabled people as workers. Instead, they seem to have assumed that, once injured, disabled workers simply left the workforce. ${ }^{29}$ Not only does this obscure the historical meaning of work and impairment; it also reinforces inaccurate and harmful ideas about the productive capacities of disabled people. Sarah Rose and others have drawn attention to the significance of disability 'as a metaphor and as a key historical aspect of working-class life and communities'. For Rose, incorporating a 'disability perspective' into histories of labour and workingclass life has the potential to transform our understanding of industrial relations, work, dependency and citizenship. ${ }^{30}$ By critically engaging with the industrialisation thesis, this book similarly opens up new avenues of inquiry that have significant ramifications for fields beyond disability studies and the way disabled people are viewed today.

\section{Coalmining in Britain, 1780-1880}

Coalmining has been chosen as the focus of this study because it was central to the economic development of modern Britain and its workers were at high risk of occupational disease and injury. Not only did mining predate the coming of factories, it also helped shape their development in crucial ways. As E. A. Wrigley has argued, the increasing exploitation of fossil fuels from the late eighteenth century onwards removed significant barriers to the scale and location of industrial expansion. ${ }^{31}$ Shifting from burning wood to coal removed competition for a natural resource upon which there were other demands that restricted its use. This enabled the widespread use of steam power and a move away from a reliance on water-driven technologies, freeing industry to expand into areas away from fast-flowing streams. ${ }^{32}$ The transition to new 
sources of fuel began from the 1770 s and between 1820 and 1870 coal was put to a wide range of industrial uses. ${ }^{33}$ While coal was not the sole reason for the expansion of British manufacturing from the mid-eighteenth century, its near universal adoption in the nineteenth century certainly facilitated continuous growth in both production and population. ${ }^{34}$ Coal powered the engines, mills and furnaces that drove the Industrial Revolution. It also fuelled the ships and locomotives that transported goods, materials, and people to far-off places, both within the British Isles and beyond. Consequently, British industry was able to exploit distant markets, as well as draw labour from further afield easier than ever before.

In addition, mining was a magnet to industry, enticing many industrialists whose businesses depended on huge quantities of coal to locate their enterprises in the coalfields. ${ }^{35}$ The sinking of new pits led to the rapid expansion of new communities and an influx of people from far and wide. As an article in the Penny Magazine (1835) put it: ' [i] f a new colliery is opened in a part of the country where such work had not previously existed, the colliery village springs up in necessary connexion with it." ${ }^{36}$ The speed and scale of population growth and urbanisation in mining areas is indicated by the example of the Easington district in north-east England. In November 1840, a government official reported that the population there had more than doubled since the mid-1830s due to the opening of new collieries and had necessitated the formation of a new town, Seaham Harbour. ${ }^{37}$ The expansion of coalmining was a catalyst for demographic change and migration that were the hallmarks of industrial Britain. Rising demand for coal also stimulated technological innovations in coalmining itself and the growth of extensive transport networks to service mining, as coal owners sought to reduce their costs and supply far away markets. $^{38}$

Coalmining's importance and dramatic expansion in the nineteenth century is powerfully illustrated by output figures for the period. Although national output statistics are approximate before the 1872 Coal Mines Act mandated better collection of production data, annual output in 1700 was estimated to have been just under three million tons, rising to roughly five million by 1750 and over thirty million by $1830 .{ }^{39}$ By the 1870 s output had reached 128 million tons and would rise even more dramatically to a peak of a little over 228 million by the outbreak of the First World War. Employment in the sector at this time grew at a similar rate. In 1800 an estimated 40,000 persons worked in the coal industry. By 1880 , the figure stood at around $485,000 .^{40}$

However, the expansion of the coal industry was uneven and marked by distinctive regional differences. As Figure 1 indicates, the main centres of coalmining in nineteenth-century Britain were north-east England, central 


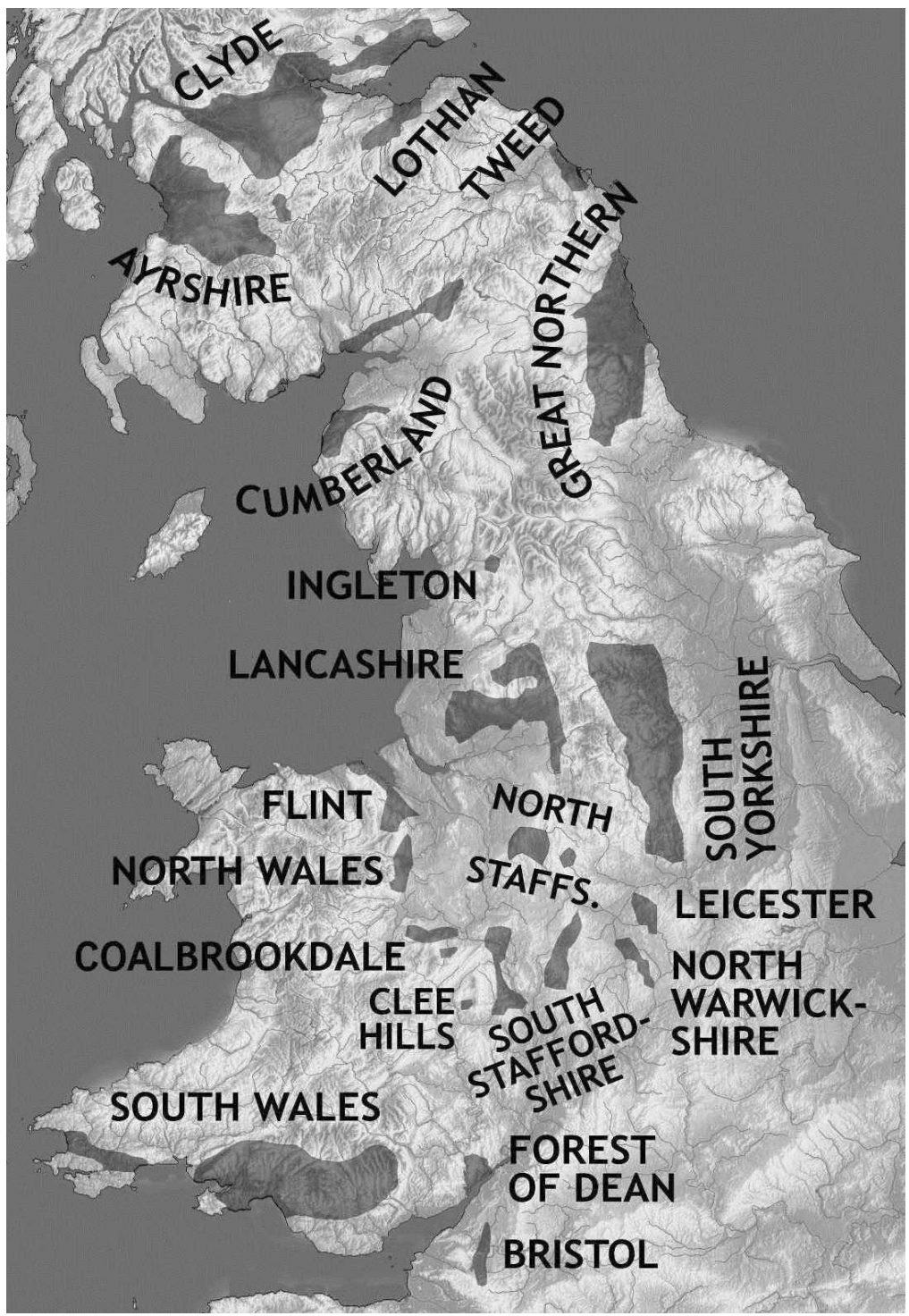

Figure 1 British coalfields in the nineteenth century, adapted from R. A. S.

Redmayne, 'The Coal-Mining Industry of the United Kingdom', The Engineering Magazine, xxvi (1904). Credit: Notuncurious/Wikimedia Commons/CC-BY-SA-3.0. 
Scotland, Lancashire, Yorkshire, the English Midlands and south Wales. This book pays special attention to those in central Scotland, north-east England, and south Wales, as these were three of the most significant coal producing regions, which reflect the varying pace of development of the industry during this period and the related differences in work cultures and conditions. Of these, the Great Northern Coalfield of north-east England was the oldest and largest, already employing 13,500 workers at the start of the nineteenth century. During the period 1780-1880, it remained the most important in Britain, both in terms of production and the numbers employed. However, north-east England's overwhelming dominance in mining, was gradually eroded during the course of the nineteenth century, due mainly to the dramatic rise of the south Wales coal industry from the 1840s. South Wales was the fastest growing coalfield during this period, producing about 20 per cent of the nation's coal by 1913. Scottish coalmining also experienced changing fortunes over the nineteenth century. In 1800 it accounted for around 20 per cent of the estimated total British coal production. Eighty years later, although its output had risen, its overall share of British output had fallen to 12 per cent, thanks to rapid expansion of mining in other regions. ${ }^{41}$

There were furthermore significant geological variations between (and within) coalfields that affected the rate, scale and methods of extraction, which in turn influenced the social organisation of mining communities. ${ }^{42}$ Coal was a heterogeneous material. There were differences in the types and qualities of coal and the depths of mines needed to extract it. Bituminous coal was widely used for domestic heating and smelting metals. Usually found fairly close to the surface, it was relatively easy to mine and could be worked using comparatively cheap open-cast or drift mining techniques. Steam coal, in contrast, was further from the surface and more costly to mine. ${ }^{43}$ As we shall see, geological differences between and within coalfields affected the risks coalminers faced since these influenced factors such as a mine's susceptibility to roof falls or the volume of dust inhaled by miners. Recognising the economic and cultural variations in Britain's coal industry during the Industrial Revolution illuminates the uneven nature of industrialisation, but it also compels us to see the diversity in 'disabled' people's experiences. As we shall see, the differences between and within the three coalfields chosen in this study were reflected in distinctive working practices, industrial relations and welfare provision for sick and injured miners that shaped the lives of disabled people in mining communities in multiple ways. By bringing in perspectives from different parts of Britain, this book further resists the homogenising impulse found in previous accounts of disability and the Industrial Revolution.

As mining expanded, British policymakers and the public became more 
aware of the shocking toll coal production took on the bodies of mineworkers. The number and scale of accidents in an industry regarded as vital to the economy, led to increasing regulation of the industry through official inspection..$^{44}$ At the same time, the question of how to provide for the many men, women and children badly hurt or 'worn out' in the service of mining inspired new welfare and medical responses. These initiatives helped make disability visible to British society and contributed to the idea, still popular today, that physical impairment is above all else a 'problem' that needs solving. Coalmining not only powered the Industrial Revolution, then, it also shaped emerging understandings and experiences of disability in nineteenth-century Britain that linger on, affecting the lives of disabled people in the present. Consequently, a disability history of British coalmining like this is long overdue.

\section{Approach and methodology}

While disability remains a neglected topic in histories of industrialisation, greater attention has been given to occupational diseases, working-class health and the regulation of nineteenth-century workplaces. Indeed, mining has occupied an important place in this scholarship. In his path-breaking book on The Diseases of Miners (1943), for example, George Rosen traced the evolution of medical thinking about the occupational health problems of mineworkers, particularly lung diseases. ${ }^{45}$ Recent studies have added to Rosen's discussion by demonstrating that trade unions as well as doctors have been pivotal in producing medical knowledge. ${ }^{46}$ Historians of occupational medicine have also highlighted industrial accidents and illnesses as evidence of the hardships faced by workers in the past, and the example of sick or injured workers has been used to explore working-class access to medical services via the Poor Law, employer paternalism, or voluntary benefit schemes. ${ }^{47}$ For Paul Weindling, occupational health history provides a 'sensitive index of social conditions in industrial societies', and 'shows the power of the labour process to structure the everyday reality outside the workplace' ${ }^{48}$ Responses to the medical problems caused by the rapid expansion of urban industrial communities have been documented through studies of hospitals and other medical services. ${ }^{49}$ Historians have also examined the nineteenth-century state's growing interest in regulating workplaces as part of a broader campaign for public health, linked to middle class reformism. ${ }^{50}$ This has stimulated valuable research on the evolution of health and safety policy through nineteenth-century regulation of mining, factories and other 'dangerous trades', and on changing attitudes towards risk and accident prevention that led to new laws on workmen's compensation. ${ }^{51}$ 
The best of this work recognises that the history of workplace accidents and diseases is not simply a matter of medical diagnosis or public policy, but also about individual experiences. For example, in Caught in the Machinery (2008), Jamie Bronstein argues that the meanings of injury in industrialising Britain were formed in the 'multiple contexts in which it was experienced', and that the personal consequences of workplace accidents were contingent on many factors, including the nature of the injury, the skill of the worker involved and the attitudes of employers. She also examines the cultural representation of accidents - in mining as well as other sectors - and charts the relationship between work, injury and masculine identity. ${ }^{52}$ However, her principal focus is on the evolution of Anglo-American employer liability law, which precludes further analysis of the ability of injured miners and other workers to return to employment, of how disability was experienced within working-class communities, or of the role played by injured or impaired workers themselves in industrial politics.

In this book we take a disability history approach to workplace accidents and ill health. This differs from conventional occupational health histories in that it seeks a more holistic approach to the experiences of injured and diseased workers - one that goes beyond the worlds of work and medicine to include consideration of other important aspects of disabled people's lives. Thus, the home, the family, the church, the courtroom and even the marital bed are equally important sites for investigation by disability historians as the workplace, hospital or poorhouse. Viewed from such a multi-dimensional perspective, 'disabled' people are seen as much more than mere patients, dependents or incapacitated workers. Instead, they become recognisable as the parents, spouses, brawlers, plaintiffs and respected members of their communities they also were. Highlighting and examining the diverse range of roles occupied by disabled people in the past enables their historical agency to be brought more fully into the spotlight, revealing the ways in which they have actively shaped their own lives and those of the people around them. Just as significantly, it also suggests how the multiple identities assumed by disabled people - as parents, workers, 'club' members and so on - affected their experiences of disability and its impact on their lives. Furthermore, although they were indeed the recipients of care, treatment or support, this was rarely, if ever, a top-down process, with health and welfare professionals wielding unrestrained power over disabled people. Instead, it was more often a process of negotiation marked variously by resistance, acquiescence and compromise on the part of both parties. Consequently, such circumstances enabled many disabled people to help fashion the treatment they received. Considering the effects of impairment from multiple perspectives, then, deepens our 
understanding of the contingent nature of disability and how it can mean very different things in different contexts and is always open to contest. ${ }^{53}$

In the pages that follow we focus primarily on physically disabling and chronic conditions that had an occupational basis in coalmining, such as amputation, mobility impairment, visual impairment and chronic illness, such as respiratory disease, which caused progressive 'debility'. We also examine the range of physical deformities and bodily markings associated with mining, from spinal curvature to scars and unusual facial features. Although our emphasis is on physical rather than mental impairment, we acknowledge that psychological illness did sometimes interact with physical conditions and that trauma and disease affected patients both physically and emotionally. Rather than engaging in retrospective diagnosis, the book explains how categories of physical disability were created and evolved. In this study the descriptive term 'disabled' is used to refer to people identified in the sources by various keywords of impairment, such as 'maimed', 'worn out', 'lame' or 'cripple', who potentially may have faced restrictions on their ability to perform everyday activities through injury, disease, congenital malformation, ageing or chronic illness, or whose appearance made them liable to be characterised by contemporary cultural ideas associated with non-normative bodies. Nevertheless, questions remain about whether the subjects of this book would necessarily have identified themselves as 'disabled'. Modern definitions of 'disability' and 'disabled' are the result of a process of historical development and do not map easily onto understandings of impairment in the past. ${ }^{54}$

While the terms 'disabled' and 'disability' were rarely used before the twentieth century to denote a group of people defined by their physical difference or as a 'master trope of human disqualification', the period covered by this book has been identified as marking significant changes that led to the development of modern categories. ${ }^{55}$ Deborah Stone has argued that the growing use of the 'defective' category to categorise people with a range of physical, sensory and intellectual impairments from 'able-bodied' paupers within nineteenth-century English Poor Law administration, shows that people with physical difference were increasingly banded together as a 'problem' requiring specific responses. ${ }^{56}$ Lennard Davis has also highlighted the significance of the era to the modern disability category, arguing that its roots can be traced to statisticians' attempts in the early nineteenth century to measure and define 'normal' (and by implication 'abnormal') human characteristics, which subsequently fed into Social Darwinism and eugenic ideas about improving the human species later in the century. ${ }^{57}$ Despite such efforts to categorise human difference more rigorously, however, the term 'disabled' was often used in flexible ways during the formative phase of the Industrial Revolution. As 
Henry de la Beche's use of the term in the example above indicates, 'disabled' sometimes referred to those whose ability to earn their living, and support themselves and their families, was compromised. At the same time, 'disabled' could also be used to describe someone who was unable to work at his or her usual occupation, rather than a person completely incapacitated from any kind of work whatsoever. Furthermore, whereas the modern term 'disabled' relates to a permanent or long-term condition, nineteenth-century Britons also used it to refer to temporary states. ${ }^{58}$

To understand 'disabled' people's experiences during this period of industrial expansion, we need to recognise the flexibility and subtlety of contemporary languages of bodily difference. The binary positions of 'ability' and 'disability' fail to capture the full range of people's experiences in the past. ${ }^{59}$ In industrial societies where classes of workers were frequently defined by their distinctive physical peculiarities, and where accidents were common, it seems likely that many people occupied a liminal space between unimpaired physical wholeness and 'total' disablement. Take, for example, the person described by Dr James Mitchell in the 1842 Children's Employment Commission report, seriously injured, but eventually able to return to work 'a little distorted', mentioned at the start of this chapter. While he experienced lasting damage to his body, he did not fit a model of disability defined by complete physical incapacity. Chris Mounsey has argued that historical studies of disability need a new method for understanding bodily 'variability'. The uniqueness of a body, he argues is a result of its context, comprising three inter-related elements: a person's unique physical capacity; his or her capability to come to terms with his or her difference; and how these were affected and shaped by encounters with others. ${ }^{60}$ It follows, therefore, that diseased or injured coal workers' experiences were affected by the nature of their impairment and its impact on their functional abilities, by their ability to accommodate themselves to this difference and by the approach of their employers, families and communities to this difference. The latter was manifested (among other ways) by colliery managers' willingness to accept this person as an employee or find alternative work for them, by the injured or impaired person's status within her or his home or community, and by the broader set of cultural values that shaped responses to those whose bodies did not necessarily conform to the qualities deemed desirable or acceptable within these communities. Although not all these features or interactions are easily visible in the historical record, the flexibility of this method allows us to put emphasis on the uniqueness of individual experiences and avoids the homogenising and inaccurate tendency to view 'disabled' people as a 'group' in industrialising Britain. However, at the same time, it is also important to acknowledge the commonality of experience 
that has existed between disabled people in the past, despite their different personal circumstances. For example, as this book shows, injured mineworkers may have had very different impairments, capacities, skills and employers, but they still often faced the same moralistic attitudes in their dealings with friendly societies or Poor Law officials and these could affect their lives in very similar ways. In the pages that follow, then, we recognise both the common and particular features of disabled people's lives and explore how these interacted with each other to shape their experiences.

Given the fluid and variable nature of 'disability', it's difficult to quantify the number of 'disabled' people in nineteenth-century Britain. In coal, as in other industries, these difficulties are compounded by a lack of reliable statistics for accidents and occupational diseases for the period. As Chapter 1 shows, although the growth of government regulation of mining after 1850 compelled mine owners and managers to report 'serious' accidents, fatal accidents were generally better reported than non-fatal ones. There was no official mechanism for measuring the incidence of occupational diseases, or psychological trauma either. As late as 1878, member of parliament (MP) Joseph Cowen of Newcastle noted that while the "Home Secretary received a list of the persons who were absolutely killed, [in coal mines] ... he received no return as to the number of men who had their backs injured, their ribs squeezed in, or their legs broken'. ${ }^{61}$ Mine inspectors, moreover, did not routinely collect data for time taken off work because of occupational disease and injury until the end of our period - when growing concerns among economists, medical professionals and policymakers about the effects of work-related incapacity on productivity stimulated more comprehensive documentation of time lost to sickness or injury. ${ }^{62}$ Consequently, this book takes a cultural approach to disability in industrial society that focuses on the meanings of impairment rather than quantification. Moving away from the diagnostic approach in traditional medical histories, it explores how impaired workers saw themselves, asking what scars, missing limbs, sight loss, breathing difficulties and other injuries or chronic conditions meant for those who experienced them, and how they were perceived by others.

Such an approach demands close reading of a wide variety of texts and this book uses a rich and innovative mix of sources to examine disability and its consequences in three targeted coalfields. Parliamentary debates, legislation and official reports provide a wealth of information - often neglected by historians of disability - about the working conditions in mines, the health of workers and exposure to accidents. The 1842 Children's Employment Commission Report, for example, includes numerous descriptions and firsthand testimonies of colliery employees of all ages with a variety of physical 
impairments and medical conditions, as well as the testimonies of medical men and colliery managers. Providing the most complete picture of conditions in coal mines in the middle of our period, it is used extensively in this book. Although some of the claims made by expert witnesses to official inquiries were dubious, they nonetheless help us to map out the conflicting claims that shaped public and political understandings of coal workers' health and well-being. ${ }^{63}$ Press reports and autobiographies also furnish evidence for the home life, community relations and political activities of mineworkers, including those with impairments. Methodist periodicals provide rich, if idealised, biographical accounts of miners and other workers that reveal the religious meanings attached to impairment, while newspapers of the labour movement indicate the political import of occupational injury and how it shaped miners' attitudes and approaches to industrial relations and state regulation.

The diseases of miners are explored via medical journals, treatises and hospital records. Although they foreground professional perspectives, they also reveal ways in which patients took their own decisions about their treatment. The complex responses to the welfare needs of those injured or disabled in the coal industry are documented in Poor Law papers and in friendly society records, which provide evidence of the ways in which miners took responsibility for planning for their own ill health or disability. Documents recording distinctive responses to disability in the coalfields, such as the Northumberland and Durham Miners' Permanent Relief Fund established in 1862 are examined in order to shed light on miners' self-conscious distancing from state-funded welfare under the Poor Law. Taken together, these sources open up new angles of vision on how ideas about disability were created and mediated in various social, textual and administrative settings. Reading institutional and administrative records 'against the grain' and alongside a variety of sources produced in other contexts, allows us to tease out and analyse the distinctive responses to disability among miners, their families and communities.

\section{Chapter outline}

This book comprises five thematic chapters. These examine the economic, medical and welfare responses to disease, injury and impairment among coal workers, and discuss experiences of disability within the context of social relations and the industrial politics of coalfield communities. Chapter 1 provides the context for those that follow by providing an overview of the conditions of work in British coalmining between 1780 and 1880. It pays close attention to the nature and variety of work at collieries and in coalfield settlements in order to better understand how economic conditions shaped the in/ability 
of disabled workers to remain productive. Chapter 2 turns its attention to the principal causes of disablement in the nineteenth-century coal industry and the medical responses to them. Often admired for their physical prowess, miners appeared to embody an ideal of working-class able-bodiedness. But increasingly, from the end of the eighteenth century, the risks to health posed by coalmining began to attract medical attention. Mineworkers, moreover, were one of the first sections of the industrial working population to become accustomed to the services of doctors and surgeons via colliery sick clubs, and their interaction with medical professionals helped shaped subsequent working-class experiences of medical care. Chapter 3 extends the discussion of responses to disability by examining the welfare provisions for miners with long-term restrictive health conditions. It examines how miners and their families negotiated a 'mixed economy' of welfare, comprising family and community support, the Poor Law, and voluntary self-help as well as employer paternalism.

Chapter 4 shifts attention away from medicine and welfare towards the ways in which disability affected social relations within coalfield communities. It explores how disability shaped the identities of men and women, focusing in particular on the community, family and religious life. Chapter 5 explores the place of disability in industrial politics and how fluctuating industrial relations affected the experiences of disabled people in the coalfields. It examines how labour leaders and their allies used the rhetorical figure of the disabled miner to advance a range of causes from better provision for injured mineworkers to improved working conditions more generally. While such representations often emphasised the suffering associated with disability, the chapter shows that impaired miners were rarely passive victims. On the contrary, it demonstrates that many took an active role in industrial politics. The chapter concludes by considering workers' successful fight for better compensation laws and the impact this had on the employment prospects of disabled miners.

\section{Notes}

1 Edward Kentish, An Essay on Burns, In Two Parts: Principally on those Which Happen to Workmen in Mines from Explosions of Carburetted Hydrogen Gas (London: Longman et al. 1817), Part 1, 129, 133.

2 Helen and Baron Duckham, Great Pit Disasters. Great Britain, 1700 to the Present Day (Newton Abbott: David and Charles, 1973).

3 John Benson, 'Non-Fatal Coalmining Accidents', Bulletin of the Society for the Study of Labour History, 32 (1976), 20-2. 
4 PP 1842 (381), Appendix to the First Report of the Commissioners. Mines. Part 1. Reports and Evidence from Sub-commissioners, 138-9, 140. Our emphasis.

5 PP 1849 (613), Report from the Select Committee of the House of Lords Appointed to Inquire into the Best Means of Preventing the Occurrence of Dangerous Accidents in Coal Mines, 16.

6 For current approaches, see Emma Griffin, A Short History of the British Industrial Revolution (Basingstoke: Palgrave Macmillan, 2006); Steven King and Geoffrey Timmins, Making Sense of the Industrial Revolution: English Economy and Society 1700-1850 (Manchester: Manchester University Press, 2001).

7 M. W. Flinn, The History of the British Coal Industry, vol. 2: 1700-1830: The Industrial Revolution (Oxford: Clarendon Press, 1984); Roy Church, The History of the British Coal Industry, vol. 3: 1830-1913: Victorian Pre-Eminence (Oxford: Clarendon Press, 1986).

8 P. E. H. Hair, 'Mortality from Violence in British Coal Mines, 1800-50', Economic History Review, 21:3 (1968), 545-61; John Benson, British Coalminers in the Nineteenth Century: A Social History (Dublin: Gill and Macmillan, 1980), 40.

9 Ibid., 43.

10 Ibid., 44. Cf. Rosemarie Garland Thomson (ed.), Freakery: Cultural Spectacles of the Extraordinary Body (New York: New York University Press, 1996); Nadja Durbach, Spectacle of Deformity: Freak Show and Modern British Culture (Berkeley: University of California Press, 2008).

11 P. W. J. Bartrip and S. B. Burman, The Wounded Soldiers of Industry: Industrial Compensation Policy 1833-1897 (Oxford: Clarendon Press, 1983), ch. 5.

12 Deborah Stone, The Disabled State (Basingstoke: Macmillan, 1984); Lennard J. Davis, Enforcing Normalcy: Disability, Deafness and the Body (London: Verso, 1995).

13 Vic Finkelstein, 'Disability and the Helper/Helped Relationship. An Historical View', in Ann Brechin et al. (eds), Handicap in a Social World (Sevenoaks: Hodder \& Stoughton in association with the Open University Press, 1981), 65-78; Michael Oliver and Colin Barnes, The New Politics of Disablement (Basingstoke: Palgrave Macmillan, 2012), 52-73; Brendan Gleeson, Geographies of Disability (London: Routledge, 1999); Nirmala Erevelles, 'In Search of the Disabled Subject', in James C. Wilson and Cynthia Lewiecki-Wilson (eds), Embodied Rhetorics: Disability in Language and Culture (Carbondale and Edwardsville: Southern Illinois Press, 2001), 100-6; Penny L. Richards, 'Industrialization', in Susan Burch (ed.), Encyclopedia of American Disability History, 3 vols (New York: Facts on File, 2009), ii, 482-3; Lennard J. Davis, Enforcing Normalcy: Disability, Deafness, and the Body (London: Verso, 1995), 86-90.

14 Gleeson, Geographies of Disability, 80-98.

15 Oliver and Barnes, New Politics of Disablement, 52-73.

16 Rosemarie Garland Thomson, 'Introduction: From Wonder to Error - a Genealogy of Freak Discourse in Modernity', in Garland Thomson (ed.), Freakery, 11-12.

17 For example, Daniel Blackie, 'Disabled Revolutionary War Veterans and 
the Construction of Disability in the Early United States, c. 1776-1840' (unpublished $\mathrm{PhD}$ thesis, University of Helsinki, 2010), http://urn.fi/ URN:ISBN:978-952-10-6343-5, 109-40; Sarah F. Rose, No Right To Be Idle: The Invention Of Disability, 1840s-1930s (Chapel Hill: University of North Carolina Press, 2017); Halle Gayle Lewis, “'Cripples Are Not the Dependents One Is Led to Think": Work and Disability in Industrializing Cleveland, 1861-1916' (unpublished PhD thesis, State University of New York at Binghamton 2004); Sofie De Veirman, 'Deaf and Disabled? (Un)Employment of Deaf People in Belgium: A Comparison of Eighteenth-Century and Nineteenth-Century Cohorts', Disability and Society, 30:3 (2015), 460-74.

18 Anne Borsay, Disability and Social Policy in Britain since 1750: A History of Exclusion (Basingstoke: Palgrave Macmillan, 2005), 10-15; Gleeson, Geographies of Disability, 106-7; Oliver and Barnes, New Politics, 54-7, 60-1.

19 Griffin, Short History, 6; Maxine Berg and Pat Hudson, 'Rehabilitating the Industrial Revolution', Economic History Review, 45:1 (1992), 24-50.

20 John Williams, Was Wales Industrialised? Essays in Modern Welsh History (Llandysul, Dyfed: Gomer Press, 1995), 14-36; Griffin, Short History, chs 3 and 4.

21 Peter Kirby, Child Workers and Industrial Health in Britain, 1780-1850 (Woodbridge: Boydell Press, 2013); Pamela Sharpe, 'Explaining the Short Stature of the Poor: Chronic Childhood Disease and Growth in Nineteenth-Century England', The Economic History Review, 65 (2012), 1475-94.

22 PP 1833 (450), Factories Inquiry Commission. First Report of His Majesty's Commissioners Appointed to Collect Information in the Manufacturing Districts, as to the Employment of Children in Factories, 82.

23 William Dodd, A Narrative of the Experiences and Sufferings of William Dodd, A Factory Cripple, 2nd edition (London: L. and G. Seeley, 1841), 29, 30.

24 Steffan Bengtsson, 'Out of the Frame? Disability and the Body in the Writings of Karl Marx', Scandinavian Journal of Disability Research, 19:2 (2016), 151-60.

25 Paul Weindling, 'Linking Self Help and Medical Science: the Social History of Occupational Health', in Paul Weindling (ed.), The Social History of Occupational Health (London: Croom Helm, 1985), 7.

26 Kirby, Child Workers, 5, 12. See also P. W. J. Bartrip and S. B. Burman, The Wounded Soldiers of Industry: Industrial Compensation Policy 1833-1897 (Oxford: Clarendon Press, 1983), 10-13.

27 De Veirman, 'Deaf and Disabled?'.

28 Chris Mounsey, 'Introduction: Variability: Beyond Sameness and Difference', in Chris Mounsey (ed.), The Idea of Disability in the Eighteenth Century (Lewisburg, PA: Bucknell University Press, 2014), 5.

29 Sarah F. Rose, “'Crippled” Hands: Disability in Labor and Working-Class History', Labor, 2:1 (2005), 27-54.

30 Ibid., 29, 47. See also Edward Slavishak, Bodies of Work: Civic Display and Labor in Industrial Pittsburgh (Durham, NC and London: Duke University Press, 2008). 
31 E. A. Wrigley, Continuity, Chance and Change: the Character of the Industrial Revolution in England (Cambridge: Cambridge University Press, 1990).

32 Griffin, Short History, 107, 114.

33 Ibid., 125.

34 Ibid., 114.

35 Gerard Turnbull, 'Canals, Coal and Regional Growth during the Industrial Revolution', Economic History Review, 40 (1987), 537-60.

36 'The Collieries - No. 1', Monthly Supplement of the Penny Magazine of the Society for the Diffusion of Useful Knowledge, 28 February -1 March 1835, 123.

37 TNA, MH12/3052, Easington Union, Poor Law Correspondence, 1834-45, Letter from District Poor Law Commission Representative to the Poor Law Committee, 13 November 1840.

38 Flinn, British Coal Industry; J. H. Morris and L. J. Williams, The South Wales Coal Industry, 1841-1875 (Cardiff: University of Wales Press, 1958).

39 Church, British Coal Industry, 2; Flinn, British Coal Industry, 26, table 1.2.

40 Benson, British Coalminers, 7.

41 Ibid., 9-27, 216-17; Flinn, British Coal Industry, 5-23.

42 Stefan Berger, 'Introduction' in Stefan Berger, Andy Croll and Norman Laporte (eds), Towards a Comparative History of Coalfield Societies (Aldershot: Ashgate, 2005), 2.

43 Benson, British Coalminers, 17.

44 Catherine Mills, Regulating Health and Safety in the British Mining Industries, 1800-1914 (Farnham: Ashgate, 2010).

45 George Rosen, The History of Miners' Diseases: A Medical and Social Interpretation, with an Introduction by Henry E. Sigerist (New York: Schuman's, 1943).

46 For example, Arthur McIvor and Ronald Johnston, Miners' Lung: A History of Dust Disease in British Coal Mining (Aldershot: Ashgate, 2007).

47 For example, Leah Leneman, 'Lives and Limbs: Company Records as a Source for the History of Industrial Injuries', Social History of Medicine, 6:3 (1993), 405-27; David G. Green, Working Class Patients and the Medical Establishment: Self-Help in Britain from the Mid-Nineteenth Century to 1948 (Aldershot: Gower, 1985); James C. Riley, Sick Not Dead: The Health of British Workingmen during the Mortality Decline (Baltimore, MD: Johns Hopkins University Press, 1997).

48 Weindling, 'Linking Self-Help and Medical Science', 2, 18.

49 For example, John V. Pickstone, Medicine and Industrial Society: A History of Hospital Development in Manchester and Its Region 1752-1946 (Manchester: Manchester University Press, 1985).

50 Anthony S. Wohl, Endangered Lives: Public Health in Victorian Britain (London: J. M. Dent, 1983); Robert Gray, 'Medical Men, Industrial Labour and the State in Britain, 1830-50', Social History, 16:1 (1991), 19-43.

51 Mills, Regulating Health and Safety; Bartrip and Burman, Wounded Soldiers of Industry; P. W. J. Bartrip, The Home Office and the Dangerous Trades: Regulating Occupational Disease in Victorian and Edwardian Britain (Amsterdam: Rodopi, 2002). 
52 Jamie L. Bronstein, Caught in the Machinery: Workplace Accidents and Injured Workers in Nineteenth-Century Britain (Stanford, CA: Stanford University Press, 2008), 4, 87 and ch. 3 passim. For a similar approach, see Slavishak, Bodies of Work.

53 Beth Linker, 'On the Borderland of Medical and Disability History: A Survey of the Fields', Bulletin of the History of Medicine, 87:4 (2013), 499-535; Susan Burch and Michael Rembis (eds), Disability Histories (Urbana: University of Illinois Press, 2014).

54 Roger Cooter, 'The Disabled Body', in Roger Cooter and John Pickstone (eds), Companion to Medicine in the Twentieth Century (London and New York: Routledge, 2003), 367-84.

55 David T. Mitchell and Sharon Snyder, Narrative Prosthesis: Disability and the Dependencies of Discourse (Ann Arbor: University of Michigan Press, 2000), 3.

56 Stone, Disabled State, 29-55.

57 Davis, Enforcing Normalcy, 23-49.

58 UK Government, 'Definition of Disability Under the Equality Act 2010', https:// www.gov.uk/definition-of-disability-under-equality-act-2010, accessed 14 March 2017; cf. David M. Turner, Disability in Eighteenth-Century England: Imagining Physical Impairment (New York: Routledge, 2012), ch. 1. For the fluidity of nineteenth-century uses of 'disabled', see Chapter 3.

59 Catherine J. Kudlick, 'Comment: On the Borderlands of Medical and Disability History', Bulletin of the History of Medicine, 87:4 (2013), 551.

60 Mounsey, 'Introduction', 18.

61 Hansard, HC Deb 21 June 1878, vol. 241, cols 84-5.

62 Steve Sturdy, 'The Industrial Body', in Cooter and Pickstone (eds), Companion to Medicine, 220-1. PP 1881 [C.2903] Mines. Reports of the Inspectors of Mines, to Her Majesty's Secretary of State, for the Year 1880, 196-203.

63 Kirby, Child Workers, 5. 